\title{
The method of rational dispatching a sequence of heterogeneous repair works
}

\author{
Andrey Kostogryzov', \\ Oleg Atakishchev ${ }^{1}$, \\ Andrey Nistratov ${ }^{2}$, \\ George Nistratov ${ }^{3}$, \\ Sergey Klimov ${ }^{3}$, \\ Leonid Grigoriev ${ }^{4}$ \\ ${ }^{1}$ Main Scientific Research Test \\ Center (MSRTC) \\ and Federal Research Center \\ "Computer Science and Control" \\ of the Russian Academy \\ of Sciences (FRC CSC RAS), \\ Vavilova Street 44, bld. 2, \\ 119333 Moscow, Russia \\ Email:akostogr@gmail.com \\ ${ }^{2}$ The Russian Power Agency \\ of Ministry for the Power Generating Industry, \\ Shepkina Street 40, bld. 1, \\ 129110 Moscow, Russia \\ ${ }^{3}$ The Research Institute \\ of Applied Mathematics and Certification, \\ Krasnobogatyrskaja Street 2, bld. 2, \\ 107564 Moscow, Russia \\ ${ }^{4}$ The Gubkin Russian State University \\ of Oil and Gas, \\ Leninsky Prospect 65, \\ 119991 Moscow, Russia
}

For critically important power systems, some repair works should be performed by one repair brigade at the same time. Conditions for performing different works are often characterized by uncertainties. In practice, the term is given for each work, and possible damages exist if the performance of works is not well-timed. Taking into account these factors, the sequence of performing heterogeneous repair works essentially influences the safety and/or efficiency of the power system. The method of rational dispatching of the sequence of heterogeneous repair works considering the requirements of timeliness for their performance is proposed in this paper. The rational sequence of works is established by criteria of minimizing integral damages based on the best choices from different dispatcher technologies and their parameters (such as distribution of work call types by priorities, distribution of call priorities into groups, appointment of technologies inside groups). A possible effect is demonstrated by an example.

Keywords: criteria, efficiency, method, probability, system 


\section{INTRODUCTION}

In general, conditions of critical power system operation are characterized by a high level of uncertainty. Because of uncertainty, a set of calls for heterogeneous repair works appears, and each work should be performed in time. For one repair brigade, the daily number of calls for repairing may be estimated by dozens. In practice, the sequence of calls for performing works is defined, as a rule, by the repair brigade as it is convenient or under subjective instructions of the chief. Often there is no purposeful system coordination with the general situation, frequency of occurrence of other heterogeneous calls, time of performance of repair work, and possible damages which can follow because of delays and exceeding the repair terms.

40-50 years ago, the repair brigades were considered by the queueing theory as an example of serving systems for performing the flow of repair calls [1-4]. But this is not the case anymore. In the present article, a possibility of increasing the relative portion of well-timed performance of calls at the expense of optimization of the sequence of their performance is researched. The proposed method is based on the comparison and rational use of essentially differing properties of the following dispatcher technologies: technology for performing calls by the consecutive order "first in, first out" (FIFO) without priorities, technologies with relative and absolute priorities, technology of batch performing, and the multi-parameter technology with a combination of the listed technologies (the two last technologies have been researched earlier by authors of this article in other applications $[3,5-6,8-23])$.

\section{ABOUT TYPICAL AND PROPOSED DISPATCHER TECHNOLOGIES}

The typical mode of repair for power systems is the following. A repair brigade performs gathered calls for operating repair during a shift (or several shifts). A shift can proceed a day, halfday, 8 hours or another established period of time. In the context of this article, brigades are considered to be one continuously working brigade for serial performing calls, i.e. the brigade operates as a one-linear system of serial service of the calls flow. Because of a large load, a queue of calls can be accumulated. The formal order of a choice from the queue of calls is called a dispatcher technology. Indeed, the method of rational dispatching a sequence of heterogeneous repair works (based on the optimized dispatcher technology and other parameters) allows to meet the given system requirements for timeliness for all work calls.

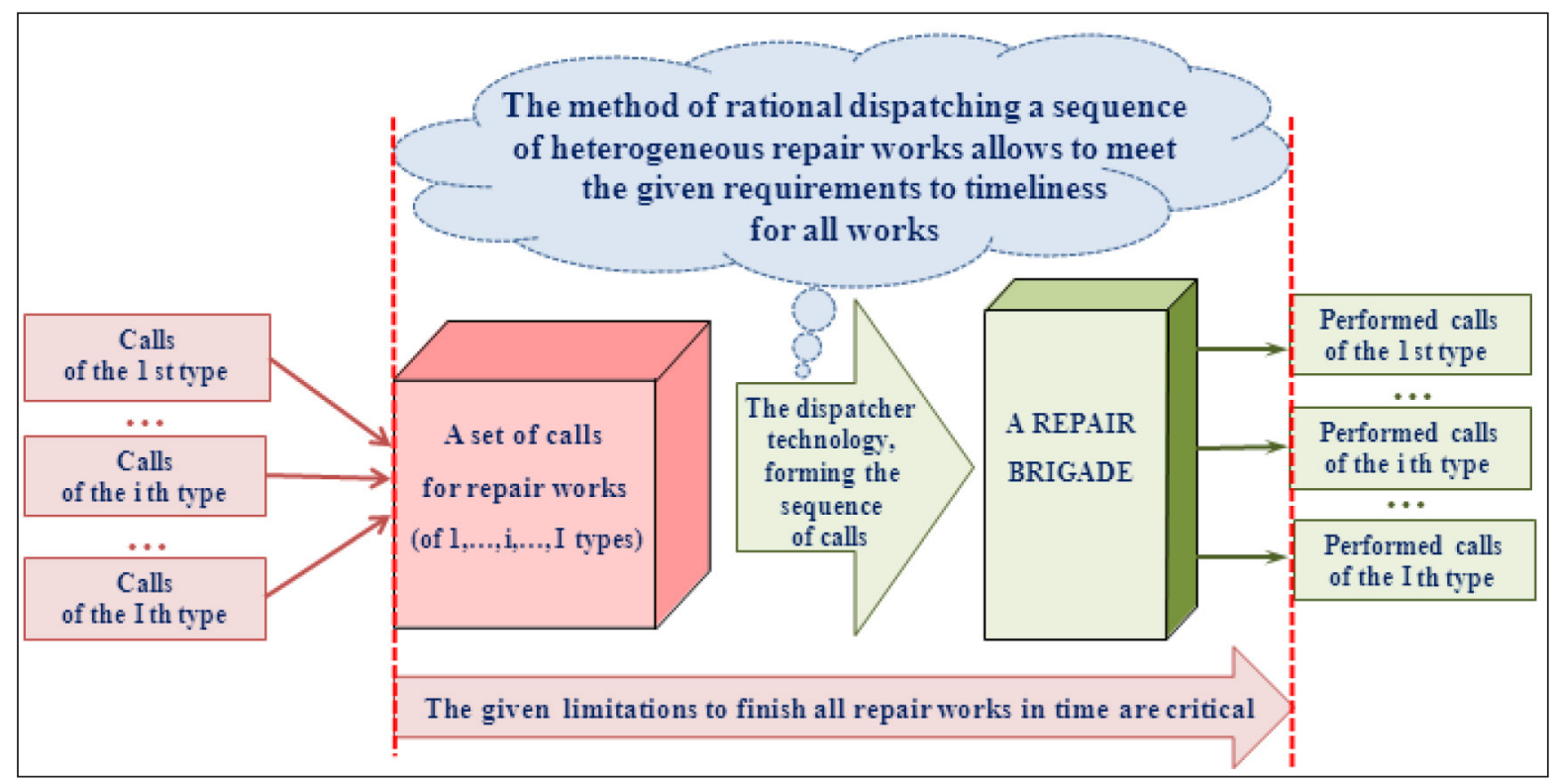

Fig. 1. Illustration of the role and place of the proposed method in performance of repair works 
Subjective reasons and momentary preferences for calls sequence are not reviewed.

The next four typical dispatcher technologies and their specific properties and the proposed 5th multi-parameter dispatcher technology are considered.

According to the technology 1 (Technology 1) all calls are performed by the consecutive order "first in, first out" (FIFO) without priorities. Its main property is that the average delays for all calls are identical. According to the technology 2 (Technology 2) calls are performed with relative priorities, numbered from 1 (the highest 1st priority) to I (the last lowest priority). Calls of higher priority have advantage against calls of lower priority, namely: among the calls waiting the beginning of performing, calls of higher priority are performed ahead of calls of lower priority. The calls with the similar priority are performed in the order FIFO. The call of higher priority cannot interrupt the call performing with lower priority. It means that the brigade always leads up the begun repair to the end, despite arrival of a new call with higher priority. The main valuable property of Technology 2 is that average delays of repair by calls of the lowest priority are 3-5 times longer (delay can be 10 and more times longer for high loading) than delays of calls of higher priority. According to the technology 3 (Technology 3) calls are performed with absolute priorities. In difference from Technology 2 new calls of higher priority absolutely interrupt the performance of calls with a lower priority. The calls with the similar priority are performed in the order FIFO. The interrupted call will be completed from the interrupted point. It means the brigade interrupts the begun repair for the call with lower priority after arrival of a new call with higher priority. The brigade carries out the completion of the interrupted repair after the completion of all calls with higher priorities. The main valuable property of Technology 3 is the following: the average delays of repair by calls of the lowest priority are 10-20 times longer (delay can be 50 and more times longer due to high loading) than delays of calls of higher priority.

According to the batch technology 4, calls are performed with the natural formation of batches and relative priorities in a batch. The first ar- rived call forms the first batch. The next batch is formed of the calls which have arrived during the total performing time of the previous batch. The next batch of calls starts to be served at once after complete performance of all calls of the previous batch. In the batch which has arrived on service, the first call of the highest priority begins to be performed. After finishing the complete performance of this call, another batch calls are performed in the serial order FIFO. Repair by all calls which have entered the served batch is carried out without interruptions, irrespective of new arriving calls. The main valuable property of Technology 4 consists of the following aspects: if for Technologies 2 and 3 the calls of higher priority have an overwhelming advantage, for Technology 4 this advantage is sharply reduced. As a result, the average delays of calls of the lowest priority considerably decrease and exceed the delays of calls of higher priority no longer than 3 times. This valuable property can be effectively used in Technology 5 , allowing to combine Technologies 2, 3, and 4 .

The proposed Technology 5 is a combination of Technologies 2, 3, and 4. For Technology 5, all calls are divided into $n$ groups. Calls of the g-th group have higher priority than calls of the e-th group if $g<e(e, g=1, \ldots, n)$. In each group the priorities of calls are relative. For performing calls of g-й groups, one technology $D_{g r}$. (by Technology 2 or 4 ) is established. Between calls, е-й and g-й groups are appointed relative (see Technology 2) or absolute priorities (see Technology 3) (Fig. 2). As a result of optimization of parameters (such as distribution of call types by priorities, distribution of call priorities in groups, appointment of technologies inside groups) the combined Technology 5 is capable to possess in various degrees the valuable properties of Technologies 2, 3, and 4, see Fig. 3.

\section{THE IDEA FOR OPTIMIZATION}

Thus, a possible effect is justified by the system use of properties and reserves of dispatcher technologies in the given time limitations to finish all repair works in time (see delays specific for Technologies 1-5, Fig. 3). It allows to reduce total damages at the expense of rational manipulation of delays. 


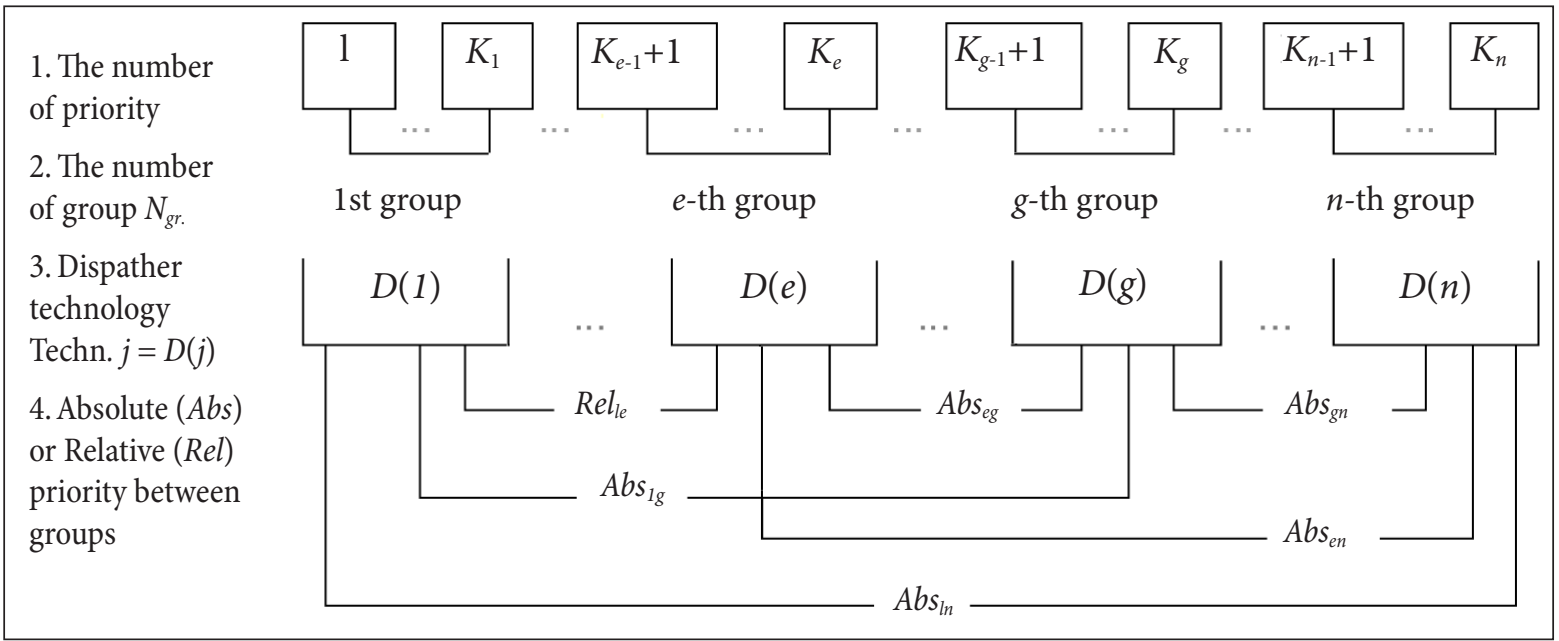

Fig. 2. The structure of the proposed combined Technology 5

As a result of total comparison by using formal criteria for each shift, the most rational technology and optimized parameters (for dispatching the sequence of calls performance), on which the minimum of negative consequences is reached with limitation of admissible time for performing heterogeneous repair works, can be revealed.

\section{FORMALIZATION FOR ESTIMATION OF POSSIBLE DELAYS}

From the point of engineering view, the processes of performing repair works by one brigade are formalized as serving processes of Poisson flows of heterogeneous calls in the one-linear system $(M / G / 1 / \infty)$ [1-6] with dispatcher technologies $1-5$. Heterogeneity of repair work is shown in various average time of calls processing and/or in various admissible terms for calls completion considering delays. The calls flows of the same type as a rule constitute a compound flow from different sources. In practice, each flow frequency is very low in comparison with the compound flow. In such a situation the theorem of Hinchin-Grigolionis [7] is applicable, according to which the compound flow is a Poisson flow.

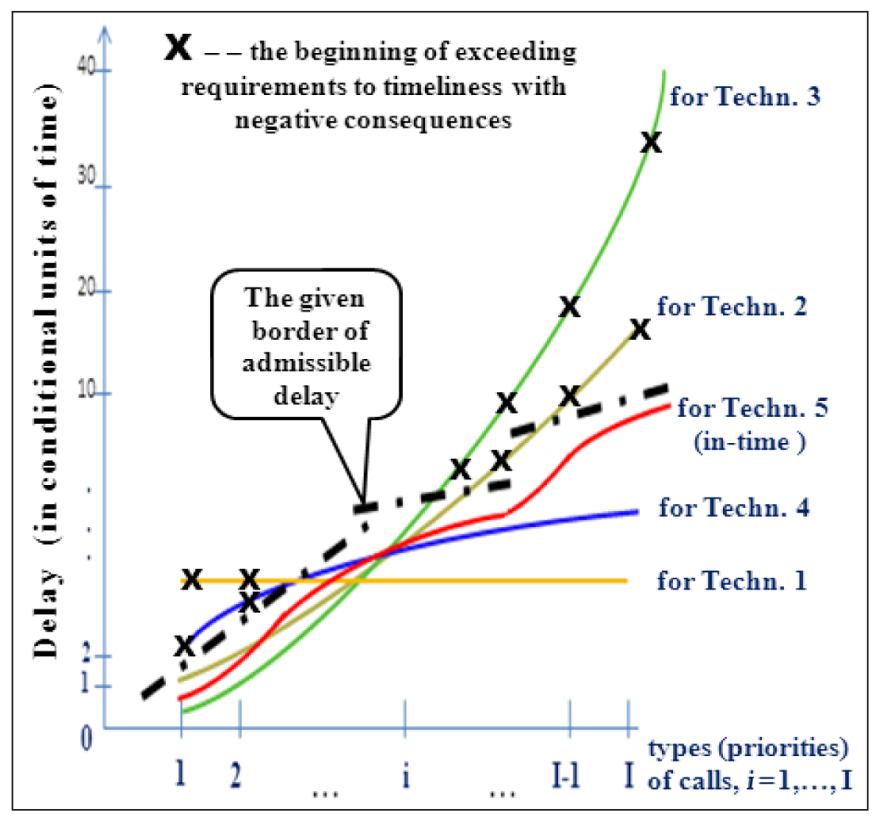

Fig. 3. The properties of Technologies 1-5 which affect time delays 
For investigated typical Technologies 1-5, the full delays in performing calls of i-th type are estimated by the probability $P_{\text {tim. } i}\left(T_{\text {given. } i}\right)$ of well-timed performing during the required term $T_{\text {given } i}$, approximated by means of incomplete gamma function:

where

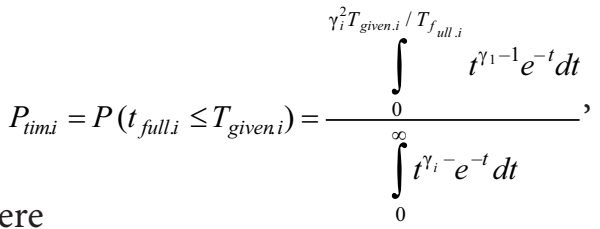

$$
\gamma_{i}=\frac{T_{\text {full.i }}}{\sqrt{T_{\text {full. } .22}-T_{\text {full. }}^{2}}} .
$$

Here $T_{\text {full. } i}$ and $T_{\text {full.i2 }}$ are according to the 1st and 2nd moments of full performing time of calls of i-th type taking into account delays. For estimations of these metrics $\left(T_{\text {full.i } i}\right.$ and $\left.T_{\text {full.i2 }}\right)$ with reference to Technologies 1,2, and 3 it is purposed to use classical models of the queueing theory $[1-2,4]$. For Technologies 4 and 5, the formulas received earlier in works $[3,5-6$, $8-23]$ are applicable. Thus, frequencies of arriving calls $\left(\lambda_{i}\right)$ and the average time of performing calls of $\mathrm{i}$-th type $\left(\beta_{i 1}\right)$ form an input for modelling. Evaluations can be carried out with the use of software tools complexes, for example the software tools Complex for Evaluation of Information Systems Operation Quality (CEISOQ) - "know how" (registered by Rospatent N2000610272), "Mathematical modelling of system life cycle processes" - "know how" (registered by Rospatent N2004610858), "Complex for evaluating quality of production processes" (registered by Rospatent N2010614145) [8-23].

\section{THE METHOD FOR OPTIMIZATION}

The following method of rational dispatching a sequence of heterogeneous repair works is proposed:

A sequence of performing heterogeneous repair works is the most rational for a repair brigade according to the technology (from Technologies 1-5) and with those parameters on which the minimum of total expected damage is reached. The following formalization is proposed: to find the minimum of total expected damage within limits of time admissible for performing heterogeneous repair works set by criterion 1 or 2 (defined below) and define the best technology and its parameters for this minimum:

$$
\left(\Sigma_{i=1}^{I} \lambda_{i} R_{i}\left(T_{\text {given. } i}\right) U_{i}\left(\operatorname{Ind}\left(\alpha_{1}\right)+\operatorname{Ind}\left(\alpha_{2}\right)\right)\right) / \lambda \underset{\substack{\text { dispatcher } \\ \text { technology }}}{\rightarrow} \min ,(3)
$$

where:

$\lambda_{i}$ - frequency of arriving calls of $\mathrm{i}$-th type, $\lambda=\sum_{i=1}^{I}$;

$R_{i}\left(T_{\text {given. } i}\right)$ - probability of exceeding the requirements of timeliness for performing calls of i-th type;

$R_{i}\left(T_{\text {given. } i}\right)=1-P_{\text {tim. } i}\left(T_{\text {given. } .}\right), P_{\text {timi }}\left(T_{\text {given. } i}\right)-$ probability of well-timed performing of works by calls of $\mathrm{i}$-th type during the required term $T_{\text {given } i}$;

$U_{i}$ - expected value of comparable damages as a result of exceeding the requirements of timeliness for performing calls of $\mathrm{i}$-th type;

$\operatorname{Ind}\left(\alpha_{1}\right)=1$ if timeliness criterion 1 is used, else $\operatorname{Ind}\left(\alpha_{1}\right)=0$;

$\operatorname{Ind}\left(\alpha_{2}\right)=1$ if timeliness criterion 2 is used, else $\operatorname{Ind}\left(\alpha_{2}\right)=0$.

The timeliness criteria 1 and 2 are defined formally as follows:

Definition of criterion 1: Works of i-th type are considered to be well-timed if the average time for full performance of calls of $i$-th type taking into account delays does not exceed the given $T_{\text {given. }}$ i.e. if $T_{\text {full.il }} \leq T_{\text {given. } i .}$

Definition of criterion 2: Works of i-th type are considered to be well-timed if probability of welltimed performing of works by calls of $\mathrm{i}$-th type during the required term $T_{\text {given } i}$ is not below admissible probability $P_{\text {tim.i } i}=P\left(t_{\text {full.i }} \leq T_{\text {given. } .}\right) \geq P_{\text {adm. } .}$, where the random variable $t_{\text {fulli } i}$ characterizes the full time for performing works of i-th type taking into account delays. The criterion 2 sets most stringent conditions (as a rule $P_{\text {adm.i }} \geq 0.8$ ) and is used when completion of called works should be finished strictly before the required time.

At the formation of input data for evaluation, the frequency of arriving calls of i-th type is defined for the last period of time (for example, for a week or month with a proper quantity of calls for repair works) as the ratio of the quantity of calls to the duration of the considered period.

The solution of the optimization problem is carried out before the beginning of each shift and is valid during the shift. 
The optimization is carried out by modelling

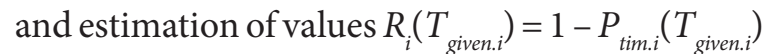
with the use of formula (1) by search of all possible dispatcher technologies and variants of parameters (such as distribution of call types by priorities, distribution of call priorities in groups, appointment of technologies inside of groups). The most rational sequence of performing heterogeneous repair work is the sequence that corresponds to the dispatcher technology with the parameters for which the total expected damage is minimal.

\section{EXAMPLE OF RATIONAL DISPATCHING}

Let's assume that a large power system considers the ways of increasing system efficiency at the expense of decreasing the cost of repairs. 7 types of repair works are characteristic of the system, for example, according to IEC 61508-2 "Functional safety of electrical/electronic/programmable electronic safety-related systems - Part 2: Requirements for electrical/electronic/programmable electronic safety-related systems", these may be: 1st type - repair of input devices, including primary sensors, trip initiating values (set-points) of all inputs; 2nd type - repair of alarm functions; 3rd type - repair of functions of all final control elements and output modules; 4th type - repair of the function of user-initiated diagnostics; 5th type - repair of operations causing the demand requiring compensating measures, the correct use of compensating measures to prevent unsafe state and/or reduce the consequences of specified hazardous events; 6th type - repair of the function of the manual trip to bring the system to its safe state; and 7th type - repair of complete system functionality.

Let the exceeding of given terms leads to the same damages for each type of repair, i.e. $U_{i}=U$. The repair brigade performs works by Technology 1 (FIFO) or by batch technology 4 (forming batches of arrived calls and performing works without interruptions). For the expired month frequencies of arriving calls $\left(\lambda_{i}\right)$, average time of performing calls of $\mathrm{i}$-th type $\left(\beta_{i 1}\right)$ by a repair brigade, and requirements to terms of performing all works form the input data for modelling. The terms for the first types (1-6) are defined as harder requirements by criterion 2 , and the terms for type 7 by criterion 1 (see the Table).

It is required to do optimization of the sequence of performing heterogeneous repair works and to estimate the effects reached.

Considering that the expected value of the missed benefit in the conditions of the example is identical (equal to $U$ ), the total expected damage can be transformed to the form:

$$
\begin{aligned}
& \left(\sum_{i=1}^{I} \lambda_{i} R_{i}\left(T_{\text {given. } i}\right) U_{i}\left(\operatorname{Ind}\left(\alpha_{1}\right)+\operatorname{Ind}\left(\alpha_{2}\right)\right)\right) / \lambda= \\
& =U(1-\mathrm{C}),
\end{aligned}
$$

where $C$ is a relative portion of well-timed performed calls

$$
\mathrm{C}=\left(\sum_{i=1}^{I} \lambda_{i} P_{\text {tim. } .}\left(T_{\text {given. } i}\right)\left(\operatorname{Ind}\left(\alpha_{1}\right)+\operatorname{Ind}\left(\alpha_{2}\right)\right)\right) / \lambda .
$$

For modelling and estimations, software tools complexes CEISOQ [8-23] are used, see results on Fig. 5.

Table. Input data for modelling

\begin{tabular}{c|c|c|c|c}
\hline $\begin{array}{c}i-\text { type } \\
\text { of heterogeneous } \\
\text { calls for repair works }\end{array}$ & $\begin{array}{c}\boldsymbol{\lambda}_{i} \text { - frequency } \\
\text { of arriving calls for } \\
\text { repair works }\end{array}$ & $\begin{array}{c}\boldsymbol{\beta}_{\text {i1 }} \text { - average time } \\
\text { of performing } \\
\text { repair works }\end{array}$ & $\begin{array}{c}T_{\text {given. }} \text { - given } \\
\text { term for repair } \\
\text { work }\end{array}$ & $\begin{array}{c}P_{\text {adm.i }} \text {-admissible probability of } \\
\text { well-timed performing of works } \\
\text { during } T_{\text {given. } .} \text { (for criterion 2) }\end{array}$ \\
\hline 1 & 2.1 week $^{-1}$ & 0.2 day & 1 day & 0.98 \\
\hline 2 & 1 week $^{-1}$ & 0.2 day & 1 day & 0.95 \\
\hline 3 & 3 week $^{-1}$ & 0.2 day & 2 days & 0.9 \\
\hline 4 & 11.5 week $^{-1}$ & 0.2 day & 3 days & 0.9 \\
\hline 5 & 1.1 day $^{-1}$ & 0.2 day & 10 days & 0.8 \\
\hline 6 & 0.1 day $^{-1}$ & 0.2 week & 16 days & 0.8 \\
\hline 7 & 0.01 day $^{-1}$ & 0.2 week & 12 days & - \\
\hline
\end{tabular}




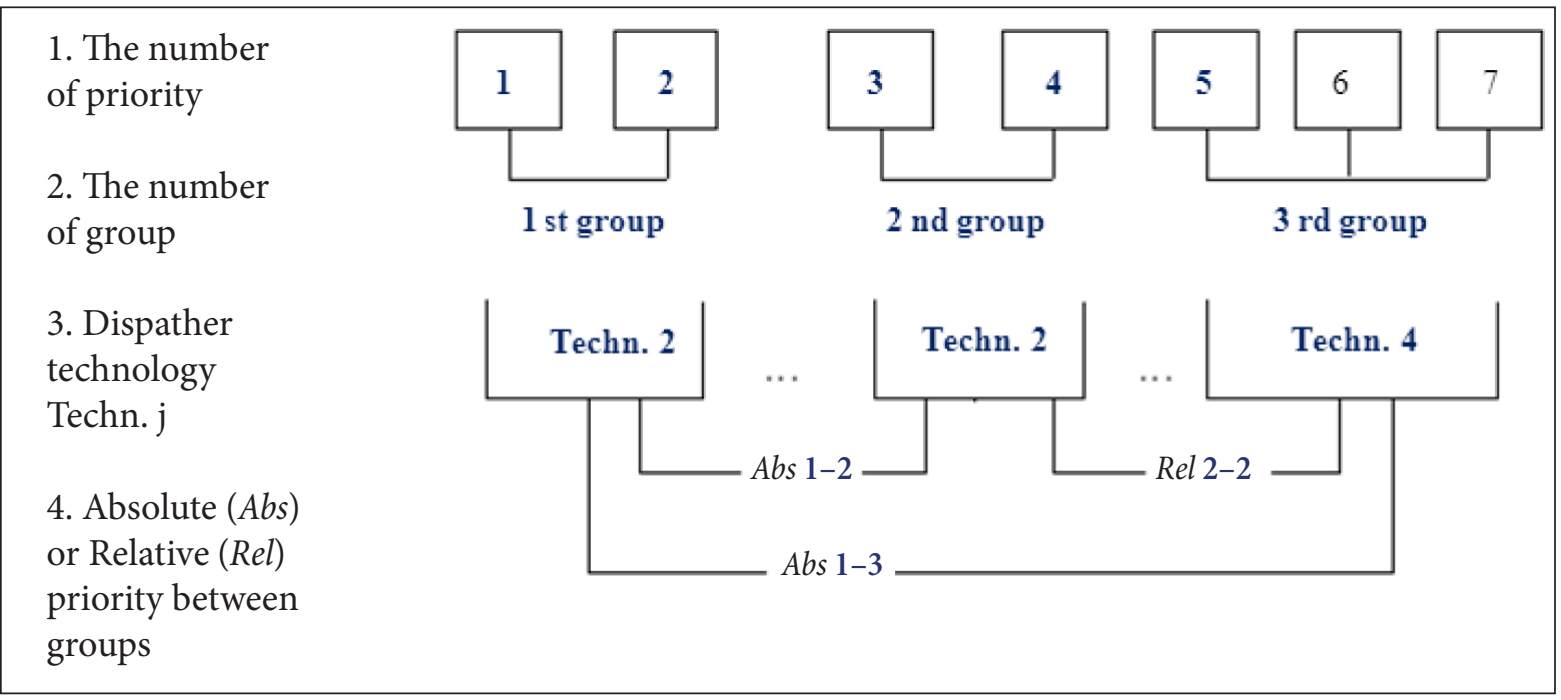

Fig. 4. Input data for modelling (columns for $\lambda_{i^{\prime}} \beta_{i 1^{\prime}} T_{\text {given.i }} P_{\text {adm.i }}$ ) and the rational parameters of Technology $5(\mathrm{~N}, \mathrm{D}, \mathrm{Abs})$

Results of the analysis have shown that at the expense of the choice of rational dispatcher Technology 5 and its optimizing parameters the relative portion of well-timed performed calls is 3 times greater in comparison with the today applied Technologies 1 and 4 . And the value of damages can be really reduced! It is because calls of 5-7th types are formed and performed in a batch (in which relative priorities without interruptions are used), but the performance of these batch calls can't be interrupted by arrival of more urgent calls of 3rd and 4th types. In turn, arriving calls of 1st and 2nd types interrupt performance of calls not only of 5-7th types, but also of 3rd-4th types. But calls of the 1st type cannot interrupt the performing of 2 nd type calls because only relative priority is used. Technology 3 is not optimal because the calls of 6th and 7th types are not well-timed. Certainly, in practice different interruptions in works are not always possible (i.e. the real effect will be a little bit low), nevertheless this effect taking into account real limitations can be estimated and it will be essential.

Note: For systems for which delays in performing repair works are insignificant, there can hardly be high practical effect from the use of the proposed ideas (the effect should be evaluated).

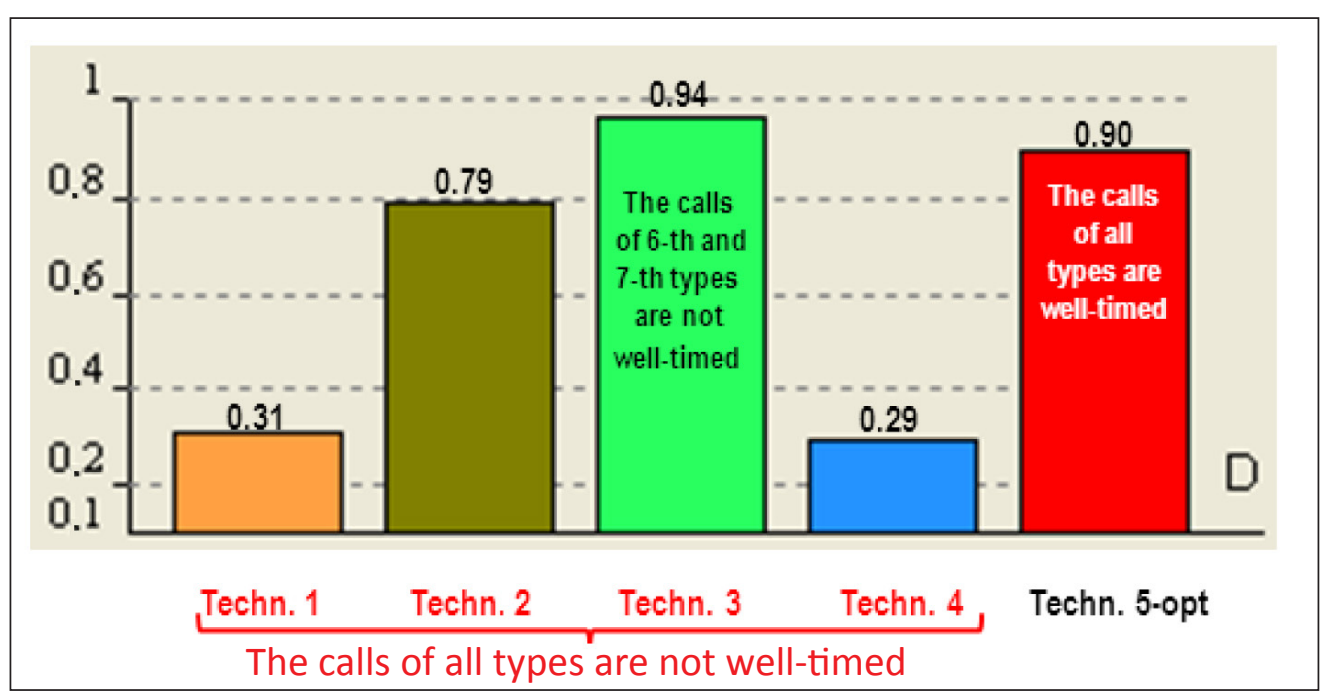

Fig. 5. Relative portion of well-timed performed calls C (optimization - on Technology 5 with parameters from Fig. 4) 


\section{CONCLUSIONS}

The proposed method of rational dispatching of a sequence of heterogeneous repair works uses the specific properties of the following dispatcher technologies: technology for performing calls by the consecutive order FIFO without priorities (Technology 1), technologies with relative (Technology 2) and absolute (Technology 3) priorities, and technology of batch performing (Technology 4). The matter is, for Technology 1 the average delays of all calls are identical, for Technology 2 the average delays of the lowest priority calls are 3-5 (and may by up to 10) times longer, and for Technology 3 even 10-20 (and may by up to 50 ) times longer in comparison with calls of higher priority; on the other hand, for Technology 4 the average delays of calls of the lowest priority considerably decrease and exceed delays of calls of higher priority no more than 3 times. These differences are used for creating a multi-parameter combined Technology 5 that may possess all the listed properties.

The method for optimization is formulated. Effects on heterogeneous repair works performing are based on finding those parameters according to which the minimum of total expected damage is reached in admissible time. In practice, the relative portion of well-timed performed calls may be increased approx. 2-3 times, in comparison with the today applied dispatching technologies.

Received 17 August 2017 Accepted 1 December 2017

\section{References}

1. Gnedenko B. V. et al. Priority Queueing Systems. Moscow: MSU, 1973. 448 p.

2. Kleinrock L. Queueing Systems, Vol. 2: Computer Applications. New York: John Wiley \& Sons, 1976.

3. Kostogryzov A. I., Nazarov L. V. Batch processing of calls with relative priorities in queueing system. News of Academy of Sciences of the USSR "Engineering Cybernetics”. 1981. No. 3. P. 194-198.

4. Matweev V. F., Ushakov V. G. Queuing Systems. Moscow; MSU, 1984. 242 p.

5. Kostogryzov A. I. Conditions for efficient batch job processing of customers in priority-driven computing systems where the queueing time is constrained. Avtomatika i Telemehanika. 1987. No. 12. P. 158-164.

6. Kostogryzov A. I. Study of the efficiency of combinations of different disciplines of the priority service of calls in the computer systems. Kibernetika i Sistemny Analiz. 1992. No. 1. P. 128-137.

7. Grigolionis V. About approximating stepped processes sum to Poisson processes. Probability Theory and Its Applications. 1963. Vol. 8. No. 2. P. 189-194.

8. Kostogryzov A. I. Software tools complex for evaluation of information systems operation quality (CEISOQ). Proceedings of the 34th Annual Event (25-29 September 2000) of the Government Electronics and Information Association (GEIA), 2000 Engineering and Technical Management Symposium, USA, Dallas, 2000. P. 63-70.

9. Kostogryzov A. I. Modelling software tools complex for evaluation of information systems operation quality (CEISOQ). Proceedings/International Workshop - Information Assurance in Computer Networks: Methods, Models and Architectures for Network Security. MMM ACNS 2001, St. Petersburg, Russia, May 21-23 2001, LNCS. P. $90-101$.

10. Bezkorovainy M. M., Kostogryzov A. I., Lvov V. M. Modelling Software Complex for Evaluation of Information Systems Operation Quality CEISOQ. 150 Problems of Analysis and Synthesis and Examples for Their Solutions. Moscow: Armament. Policy. Conversion, 2001. 303 p.

11. Kostogryzov A., Nistratov G. Standardization, Mathematical Modelling, Rational Management and Certification in the Field of System and Software Engineering (80 standards, 100 mathematical models, 35 software tools, more than 50 practical examples). Moskva: Voorusghenie. Politika. Konversia, 2004. $393 \mathrm{~s}$.

12. Kostogryzov A. I., Nistratov G. A. 100 mathematical models of system processes according International standards requirements. Transaction of the XXV International Seminar on Stability Problems for the Stochastic Models. Maiority, Italy, September 20-24, 2005, University of Solerno, Italy. P. 196-201.

13. Kostogryzov A., Nistratov G., Kleshchev N. Mathematical models and software tools to support an assessment of standard system processes. Proceedings of the 6 th International SPICE 
Conference on Process Assessment and Improvement, Luxembourg, 2006. P. 63-68.

14. Kostogryzov A., Nistratov G. Mathematical models and software yools for analyzing system quality and risks according to standard requirements. Proceedings of the 6th International Scientific School "Modelling and Analysis of Safety and Risk in Complex Systems" (MASR - 2006), Saint Petersburg, Russia, July 4-8, 2006. P. 155-163.

15. Kostogryzov A. I., Stepanov P. V. Innovative Management of Quality and Risks in Systems Life Cycle. Moscow: Armament. Policy. Conversion, 2008. 404 p.

16. Grigoriev L. I., Kershenbaum V. Ya, Kostogryzov A. I. System Foundations of the Management of Competitiveness in Oil and Gas Complex. Moskva: National Institute of Oil and Gas, 2010. 374 p.

17. Kostogryzov A., Nistratov A., Nistratov G. Applicable technologies to forecast, analyze and optimize reliability and risks for complex systems. Proceedings of the 6th International Summer Safety and Reliability Seminar, Poland, September 2012. Vol. 3. No. 1. P. 114.

18. Kostogryzov A., Nistratov G., Nistratov A. Some applicable methods to analyze and optimize system processes in quality management. In: Total Quality Management and Six Sigma. InTech, 2012. P. 127-196. http://www.intechopen.com/books/ total-quality-management-and-six-sigma/ some-applicable-methods-to-analyze-and-optimize-system-processes-in-quality-management.

19. Kostogryzov A., Grigoriev L., Nistratov G., Nistratov A., Krylov V. Prediction and optimization of system quality and risks on the base of modelling processes. American Journal of Operations Research. Special Issue. 2013. Vol. 3. No. 1A. P. 217-244. http://www.scirp.org/journal/ajor/.

20. Kostogryzov A., Nistratov G., Nistratov A. The innovative probability models and software technologies of risks prediction for systems operating in various fields. International Journal of Engineering and Innovative Technology (IJEIT). 2013. Vol. 3. Iss. 3. P. 146-155. http://www.ijeit. com/archive.php.

21. Kostogryzov A. I., Stepanov P. V., Nistratov G. A., Nistratov A. A., Grigoriev L. I., Atakishchev O. I. Innovative management based on risks prediction. In: Zheng (ed.). Information Engineering and Education Science. London: Taylor \& Francis Group, 2015. P. 159-166.

22. Kostogryzov, Grigoriev L., Kershenbaum V., Guseinov Ch., Atakishchev O., Stepanov P. The probabilistic approach to solve analytical problems in a life cycle of complex systems for developing and poweration hydrocarbon deposits of Arctic regions. The 3rd International Conference on Poweration Information and Safety, June 25 - June 28, 2015, Wuhan, P. R. China. P. 682-688.

23. Kostogryzov A., Mahutov N. (ed.), Stepanov P., et al. Security of Russia. Legal, Social \& Economic and Scientific \& Engineering Aspects. The Scientific Foundations of Technogenic Safety. Moskva: Znanie, 2015. $936 \mathrm{s.}$

Andrey Kostogryzov, Oleg Atakishchev,

Andrey Nistratov, George Nistratov, Sergey Klimov, Leonid Grigoriev

\section{IVAIRIARŪŠIŲ REMONTO DARBŲ SEKOS RACIONALAUS REGULIAVIMO METODAS}

\section{Santrauka}

Kritiškai svarbiose energetinèse sistemose kai kurie remonto darbai turi būti atliekami reguliuojant brigadų darbo laiką. Itvairių darbų atlikimo sąlygos dažnai apibūdinamos neapibrèžtumais. Praktikoje egzistuoja nustatytas kiekvieno darbo atlikimo terminas. Jei šie terminai yra pažeidžiami, galima patirti nuostolių. Atsižvelgiant ị šiuos veiksnius, ịvairiarūšių (heterogeninių) remonto darbų atlikimo seka turi reikšmingos ịtakos energetinès sistemos saugumui ir (arba) efektyvumui. Siūlomas racionalaus heterogeninių remonto darbų sekos paskirstymo metodas, atkreipiant dèmesị i laiku atliekamų darbų reikalavimus. Racionali darbų seka nustatoma atsižvelgiant i suminių nuostolių (žalų) minimizavimo kriterijus, remiantis geriausiais skirtingų dispečerinių technologijų pavyzdžiais ir jų naudojamais parametrais (tokiais kaip darbų atlikimo paraiškų paskirstymas pagal prioritetus, paraiškų prioritetų skirstymas i grupes, konkrečių technologijų nustatymas grupių viduje). Galimas efektas iliustruotas pavyzdžiu.

Raktažodžiai: kriterijus, efektyvumas, metodas, tikimybè, sistema 